\title{
OPEN Marine temperatures underestimated for past greenhouse climate
}

\author{
Madeleine L. Vickers ${ }^{1 凶}$, Stefano M. Bernasconi' ${ }^{2}$, Clemens V. Ullmann ${ }^{3,4}$, Stefanie Lode ${ }^{5}$, \\ Nathan Looser' ${ }^{2}$, Luiz Grafulha Morales ${ }^{2,6}$, Gregory D. Price ${ }^{7}$, Philip R. Wilby ${ }^{8,9}$, \\ Iben Winther Hougård ${ }^{1}$, Stephen P. Hesselbo ${ }^{4}$ \& Christoph Korte ${ }^{1}$
}

Understanding the Earth's climate system during past periods of high atmospheric $\mathrm{CO}_{2}$ is $\mathrm{Crucial}_{\text {for }}$ forecasting climate change under anthropogenically-elevated $\mathrm{CO}_{2}$. The Mesozoic Era is believed to have coincided with a long-term Greenhouse climate, and many of our temperature reconstructions come from stable isotopes of marine biotic calcite, in particular from belemnites, an extinct group of molluscs with carbonate hard-parts. Yet, temperatures reconstructed from the oxygen isotope composition of belemnites are consistently colder than those derived from other temperature proxies, leading to large uncertainties around Mesozoic sea temperatures. Here we apply clumped isotope palaeothermometry to two distinct carbonate phases from exceptionally well-preserved belemnites in order to constrain their living habitat, and improve temperature reconstructions based on stable oxygen isotopes. We show that belemnites precipitated both aragonite and calcite in warm, open ocean surface waters, and demonstrate how previous low estimates of belemnite calcification temperatures has led to widespread underestimation of Mesozoic sea temperatures by ca. $12^{\circ} \mathrm{C}$, raising estimates of some of the lowest temperature estimates for the Jurassic period to values which approach modern mid-latitude sea surface temperatures. Our findings enable accurate recalculation of global Mesozoic belemnite temperatures, and will thus improve our understanding of Greenhouse climate dynamics.

Accurately reconstructing the Earth's climate through geological time is important for understanding Earth system feedbacks and for forecasting future climate change ${ }^{1}$. In particular, past periods of highly elevated atmospheric $\mathrm{CO}_{2}$, where Greenhouse conditions prevailed, may provide important insights into climate processes operating under anthropogenically elevated $\mathrm{CO}_{2}$. The middle and late Mesozoic (Jurassic and Cretaceous; 201-66 Ma) saw such warm-climate processes, wherein polar temperatures were so high that polar ice-caps were absent most of the time $e^{2}$. Reconstructing sea and land temperatures during this interval remains challenging. Climate proxies applied to younger sediments (e.g. ice-core and tree-ring records, alkenone biomarkers) are unavailable this far back in time, and many Mesozoic sediments have undergone significant post-depositional thermal and diagenetic alteration, modifying the original composition of fossils. Nonetheless, biogenic calcite from organisms such as brachiopods, bivalves, and particularly belemnites is frequently preserved in such sediments, enabling the application of oxygen isotope thermometry for sea-water temperature reconstructions. Belemnites, emerging in the earliest Jurassic, were squid-like cephalopods (Mollusca) that built their internal skeleton from calcite and aragonite, and went extinct at the end of the Cretaceous. Their ubiquity within Jurassic and Cretaceous seas, and the high preservation potential of their low-Mg calcite skeleton (rostra), make them a favoured target for temperature reconstructions via oxygen isotope thermometry ${ }^{3-12}$. However, two major limitations to this

\footnotetext{
${ }^{1}$ Faculty of Science, Geology Section, University of Copenhagen, Øster Voldgade 10, 1350 Copenhagen K, Denmark. ${ }^{2}$ Geologisches Institut, Dep. Erdwissenschaften, ETH Zürich, Sonneggstrasse 5, 8092 Zürich, Switzerland. ${ }^{3}$ Department of Earth Sciences, University of Oxford, South Parks Road, Oxford OX1 3AN, UK. ${ }^{4}$ Camborne School of Mines, University of Exeter, Penryn Campus, Penryn TR10 9FE, Cornwall, UK. ${ }^{5}$ Department of Petrology and Economic Geology, Geological Survey of Denmark and Greenland, Øster Voldgade 10, 1350 Copenhagen K, Denmark. ' ${ }^{6}$ cientific Centre for Optical and Electron Microscopy (ScopeM), ETH Zürich, Otto-Stern-Weg 3, 8093 Zürich, Switzerland. ${ }^{7}$ School of Geography, Earth and Environmental Sciences, Plymouth University, Drake Circus, Plymouth PL4 8AA, UK. ${ }^{8}$ British Geological Survey, Keyworth, Nottingham NG12 5GG, UK. ' ${ }^{9}$ School of Geography, Geology and the Environment, University of Leicester, University Road, Leicester LE1 7RH, UK. ${ }^{\boxplus}$ email: mlv@ign.ku.dk
} 

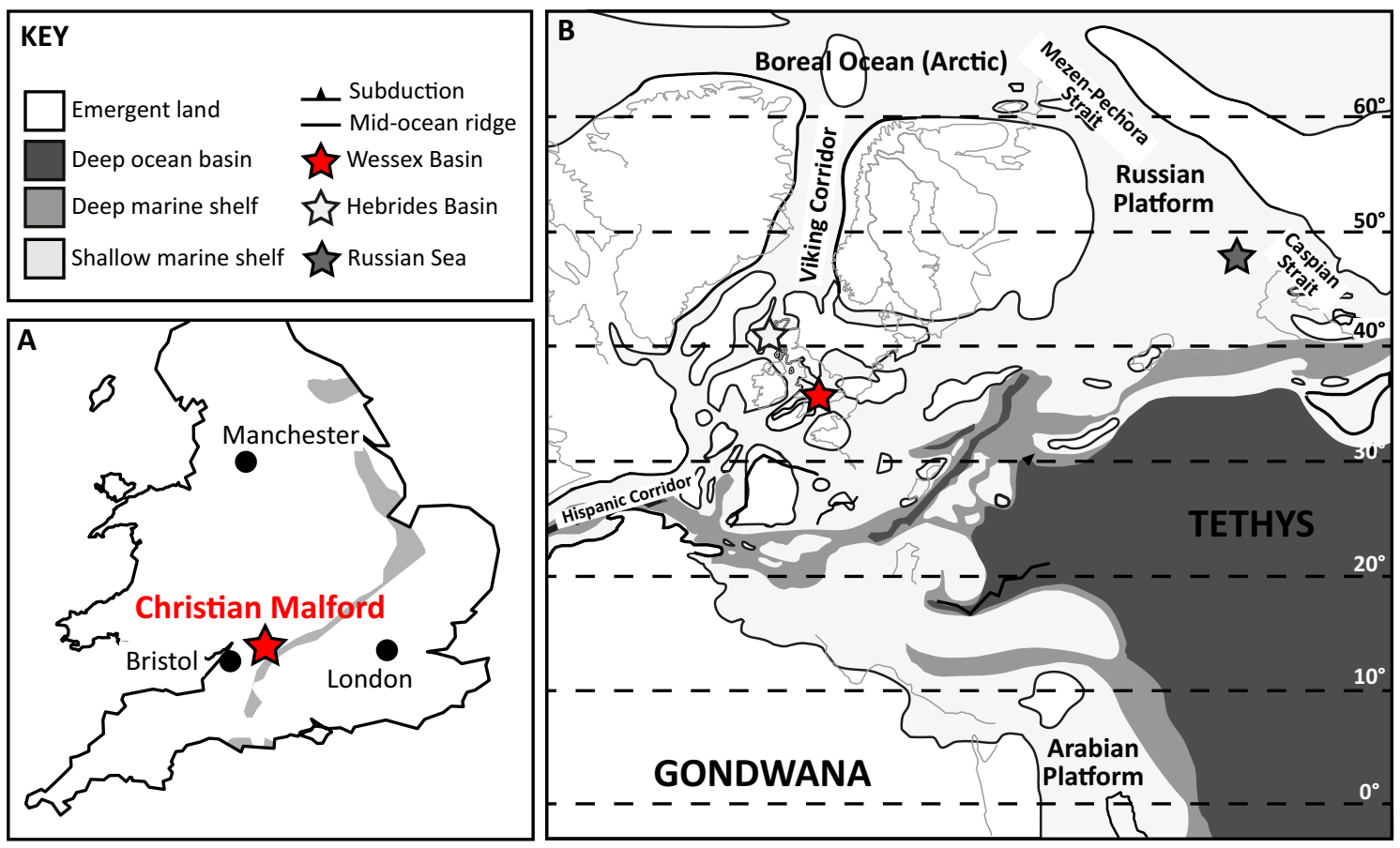

Figure 1. (A) Sampling location (Christian Malford) in the U.K., denoted by star, with the outcrop of Callovian sediments indicated by grey band, after Price et al. $^{42}$. (B) Palaeogeographic reconstruction of the Tethyan Realm during the Middle Jurassic, after Dera et al. ${ }^{63}$.

method have led to uncertainties in Mesozoic temperature reconstructions. The first is that the oxygen isotope composition of skeletal carbonates in marine systems vary as a function of both the ambient temperature and oxygen isotope composition of the seawater $\left(\delta^{18} \mathrm{O}_{s w}\right)$. Mesozoic $\delta^{18} \mathrm{O}_{s w}$ cannot be measured directly, and is usually assumed to be the average value for seawater in an ice-free world $\left(-1 \%\right.$ o SMOW $\left.{ }^{13}\right)$; yet the $\delta^{18} \mathrm{O}_{\text {sw }}$ value at a given locality and depth in the ocean may deviate from this average by as much as $4 \%{ }^{14,15}$. The second limitation is that numerous equations have been determined for the relationship between temperature and $\delta^{18} \mathrm{O}$ in different calcite types, e.g. molluscan calcite ${ }^{16-18}$, brachiopod calcite ${ }^{19,20}$, foraminifera ${ }^{21,22}$, barnacle calcite ${ }^{23}$, meteoric speleothems and cements ${ }^{24-28}$, and synthetic calcite ${ }^{29,30}$. It is not known if belemnites fractionated ${ }^{18} \mathrm{O}$ to the same extent as modern biotic carbonates, and therefore which equation, if any, is appropriate for belemnite calcite. The molluscan equation of Anderson and Arthur ${ }^{18}$ or the general synthetic calcite equation of Kim and O’Neil ${ }^{30}$ are most commonly used for belemnite calcite temperature reconstructions, yet it is observed that belemnites often give similar, or, in many cases, lower temperatures (i.e. higher $\delta^{18} \mathrm{O}_{\text {calcite }}$ ) than co-occurring benthic biotic calcites $^{3-6,8,11,31}$. It has been hypothesised that belemnites may have been migratory to areas of colder and/or isotopically distinct waters ${ }^{31,32}$, or that early diagenetic infill (i.e. as the belemnite skeleton lay on the seafloor) biases belemnite calcite to colder temperatures ${ }^{33}$, although this is disputed by other geochemical studies ${ }^{34,35}$. Furthermore, clumped isotope studies comparing the (visibly) porous apical area to the (less visibly porous) rest of the belemnite rostrum return colder temperatures for the apical area, contradicting a diagenetic cause $\mathrm{e}^{35}$. Biomarker-based $\left(\mathrm{TEX}_{86}\right)$ temperature reconstructions for shallow-buried (i.e. especially immature) Mesozoic sections similarly give much warmer temperatures than belemnite rostra ${ }^{7,36}$. As the $\operatorname{TEX}_{86}$ method is thought to record sea surface temperatures only, it was argued that the belemnites may have been nektonic or nektobenthic, living mostly below the thermocline in colder waters than the surface ${ }^{7,31}$. Yet this does not explain how belemnites may give colder temperatures than co-occurring benthic biotic calcites ${ }^{3,6,8,11,31}$. Clumped isotope thermometry reconstructs belemnite calcite temperatures closer to sea surface temperatures than bottom water temperatures, considerably warmer than oxygen isotope thermometry ${ }^{35,37-41}$. This suggests that either belemnites inhabited highly saline waters (with $\delta^{18} \mathrm{O}_{\text {sw }}$ elevated by evaporation), or that the standard calcite thermometry equations are inappropriate for belemnite calcite ch,37-41. $^{35}$.

Here we present new clumped isotope data derived from co-occurring calcite and aragonite in individual exceptionally well preserved belemnites (Cylindroteuthis) ${ }^{42}$ from the Callovian-aged Christian Malford Lagerstätte (Fig. 1). These samples are compared to other (non-belemnite) aragonites from the same horizon in order to evaluate the putative temperature record based upon the oxygen isotopic composition of well-preserved marine fossils, and thereby to resolve which oxygen thermometry equation is most appropriate for belemnite rostra in Mesozoic paleoclimate studies. In doing so, we highlight significant systematic underestimations of global sea temperature in Mesozoic reconstructions. Our warm temperatures are more in line with the geographical distributions of temperature-sensitive fossil flora and fauna, as well as the results of climate models with increased $\mathrm{CO}_{2}$ levels, and demonstrate that at least several common belemnite genera lived neither deep in the water column nor in hypersaline conditions. 


\section{Results}

Preservation. The Christian Malford Lagerstätte is known for its exceptional preservation of biomaterials in fossil marine organisms $s^{42-44}$. The host sediments have experienced minimal burial and thermal maturation as indicated by the immaturity of their organic matter ${ }^{43,45,46}$. Powder X-Ray diffraction (PXRD) confirms the preservation of original aragonite (Supplementary Fig. S3), which is uncommon in sediments this old due to the metastability of aragonite at Earth surface temperatures and pressures ${ }^{47}$, and further confirms the extremely low thermal maturity. Belemnite rostral calcite shows extremely low $\mathrm{Mn} / \mathrm{Ca}$ and $\mathrm{Fe} / \mathrm{Ca}$ values (Supplementary Fig. S12), in agreement with Price et al. ${ }^{42}$, and electron backscatter diffraction (EBSD) and scanning electron microscope (SEM) electron dispersive spectra (EDS) element maps show that no perceptible diagenetic alteration occurred in the non-apical areas of the belemnite rostra (Supplementary Figs. S7, S8, S9, S10, S11).

Whilst the aragonite and calcite appear texturally and geochemically pristine, studies have shown that clumped isotope $\left(\Delta_{47}\right)$ temperatures may be increased by re-ordering of the ${ }^{13} \mathrm{C}-{ }^{18} \mathrm{O}$ bonds ('solid state reordering'), a process by which no minor element or visible change, even at the microscopic level, occurs in the carbonate ${ }^{48-50}$. For calcite formed at ambient temperatures, this re-ordering may occur where the samples experience temperatures above $80-100^{\circ} \mathrm{C}$ over geological timescales (millions of years) ${ }^{49-51}$. Aragonite is much more prone to alteration and its reordering kinetics are much faster than those of calcite ${ }^{48}$; e.g. Ritter et al..$^{52}$ showed that such reordering may occur after 20 weeks of the aragonite being held at $100^{\circ} \mathrm{C}$. However, for the Callovian sediments at Christian Malford, burial estimates, maturity indices and diagenetic carbonate clumped isotope data suggest that such temperatures were not reached ${ }^{43,45,46}$, negating this effect. In combination, these conditions provide a unique opportunity to determine the accuracy with which belemnite rostra record original calcification temperatures and can be relied upon to faithfully record ambient marine conditions in the Mesozoic. If aragonite and calcite from the same organism yield the same temperature, we can be very confident that they represent true original temperatures, as any alteration would preferentially disrupt the values for the aragonite over the calcite.

Clumped isotope palaeothermometry. Clumped isotope compositions for the analysed calcites and aragonites range from 0.580 to 0.609 (I-CDES ${ }^{53}$; excluding separated diagenetic calcites from the apical area and spar cements), which correspond to temperatures ranging from 20.0 to $29.5^{\circ} \mathrm{C}$ based on the Anderson et al..$^{54}$ equation. Anderson et $\mathrm{al}^{54}$ found that inorganic, and most biogenic, carbonates (including aragonite) show the same temperature dependence; thus, their equation can confidently be applied to reconstruct palaeotemperatures for aragonites and calcites. Reconstructed aragonite and calcite $\Delta_{47}$ palaeotemperatures from the same belemnite are consistently within error of each other, and are in agreement with other biotic aragonites from the sample (Fig. 2A). This supports that the observed $\Delta_{47}$ temperatures are pristine. This is therefore the first study that provides seawater temperatures and oxygen isotope compositions which are proven to be unaffected by reordering.

\section{Discussion}

This study, along with other clumped isotope studies of belemnites ${ }^{35,37-41}$ finds that belemnites grew in much warmer (i.e. near-surface) waters than previous stable isotope studies have suggested ${ }^{3-12}$. Clumped isotope records show that belemnites record warmer temperatures than early (seafloor) diagenetic cements ${ }^{35}$ (Fig. 2A), consistent with recent palaeontological work that shows that some belemnites lived in the top $200 \mathrm{~m}$ of the water column ${ }^{55}$.

Traditional stable oxygen isotope thermometry (e.g. Anderson and Arthur ${ }^{18}$ equation, assumed $\delta^{18} \mathrm{O}_{\text {sw }}=-1$ $\%$ o for an ice-free world ${ }^{13}$ ) consistently returns temperatures for rostral calcite that are, on average, $9^{\circ} \mathrm{C}$ colder than for phragmocone aragonite (using the Grossman and $\mathrm{Ku}^{56}$ aragonite equation) from the same individual belemnite (Fig. 2). Whilst this phenomenon has previously been observed ${ }^{42}$, it was not possible to determine if the aragonite temperatures were too warm or if the Anderson and Arthur ${ }^{18}$ equation gives temperatures that are too cold. It is believed that belemnite calcite precipitated near $\Delta_{47}$ isotopic equilibrium ${ }^{41,57}$, and the consistency between belemnite calcite and aragonite clumped isotope temperatures (Fig. 2) suggests that belemnite aragonite also does not exhibit strong kinetic disequilibrium effects with respect to $\Delta_{47}$, despite this phenomenon having been observed in modern cephalopod aragonite ${ }^{58,59}$. In modern cephalopods, disequilibrium effects lower $\Delta_{47}$ values, i.e. yielding temperatures that are warmer than the true growth temperature, by as much as $8^{\circ} \mathrm{C}^{58,59}$, yet belemnite aragonite in this study does not yield warmer temperatures than the rostral calcite (Fig. 2A). Thus we proceed under the assumption that both calcite and aragonite from belemnites precipitated in $\Delta_{47}$ equilibrium.

Several more recent studies present equations determined for natural calcite $\delta^{18} \mathrm{O}$ grown in equilibrium. Two studies present equations derived from very slow-growing subaqueous calcites ${ }^{26,28}$. Daëron et al. ${ }^{28}$, being the most recent, is given below (Eq. 1). Another stable isotope equation derived for fast-growing travertines, is believed to reflect (near) equilibrium conditions ${ }^{27}$, yet differs from Daeron et al..$^{28}$ in having a slightly steeper slope (Eq. 2):

$$
\begin{gathered}
1000 \ln \alpha=27.57 *\left(\frac{1000}{T}\right)-29.13 \\
1000 \ln \alpha=20 *\left(\frac{1000}{T}\right)-36
\end{gathered}
$$

where $\alpha$ is the calcite/water oxygen-18 fractionation factor and $T$ is the absolute temperature in Kelvin.

We do not know the $\delta^{18} \mathrm{O}$ aragonite-water fractionation for belemnite phragmocone, yet for modern aragonitic cephalopods this effect is negligible, and closely approximates both the equilibrium calibration of Daëron et al. ${ }^{28}$, and the biogenic calibrations of White et al. ${ }^{60}$ and Grossman and $\mathrm{Ku}^{56,58,59}$. However, calcites may show 


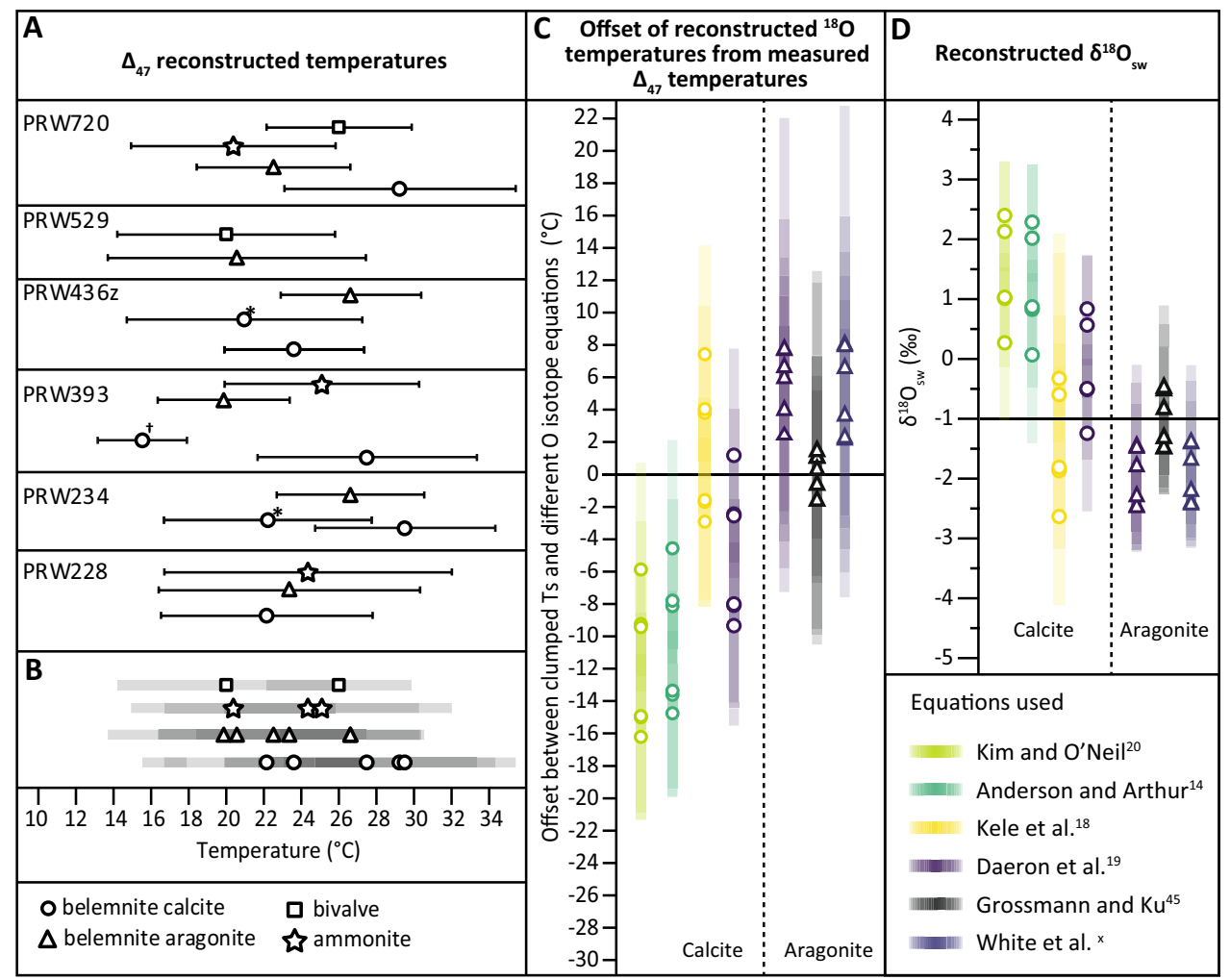

Figure 2. (A) Reconstructed temperatures from clumped isotopes (each based on 10 or more replicates) for all samples analysed (all from the Phaeinum subzone), displayed by type (rostrum, phragmocone, ammonite and bivalve) and with accompanying samples from the same block. Error bars indicate the $95 \%$ confidence interval. $\dagger=$ sample from apical area, including early diagenetic infill. ${ }^{*}=$ diagenetic sparry calcite from phragmocone chamber spaces. The calcites marked $\dagger^{\star}$ are not included in any following analyses of the data (e.g. Figure $2 \mathrm{~B}$, C or Fig. 3). (B) All samples grouped together to demonstrate the range spanned over this single subzone, not including the samples marked $\dagger^{*}$. (C) Offset of reconstructed ${ }^{18} \mathrm{O}$ temperatures (for the different equations) from measured clumped isotope temperatures. Error envelope $=$ maximum possible offset between clumped and stable temperatures based on the 95\% CL level for clumped isotope temperatures and the SD for measured oxygen isotopes.

near-equilibrium $\Delta_{47}$ yet far-from-equilibrium $\delta^{18} \mathrm{O}^{61}$, and as there are no studies on calcifying cephalopods, we do not know if the biotically-mediated precipitation of rostral calcite may have been fractionated with respect to seawater. As clumped isotope thermometry gives both the temperature and $\delta^{18} \mathrm{O}_{\text {carbonate }}$, these can be used together to back-calculate the $\delta^{18} \mathrm{O}_{\mathrm{sw}}$, using one of the stable isotope equations. It is hard to reconcile two carbonate phases from the same organism growing in different $\delta^{18} \mathrm{O}_{\mathrm{sw}}$; thus, we can select the equations that yield the most similar $\delta^{18} \mathrm{O}_{\mathrm{sw}}$ for belemnite calcite and aragonite pairs (Fig. 2D). The closest matches are between the Kele et al. ${ }^{27}$ equation for the rostra and any of the aragonite equations ${ }^{28,56,60}$ (Fig. 2D) for the phragmocone; closely followed by Daëron et al. ${ }^{28}$ for the rostral calcite with Grossman and $\mathrm{Ku}^{56}$ for aragonite (Fig. $2 \mathrm{D}$ and Supplementary data). Interestingly, applying Daëron et al. ${ }^{28}$ to both calcite and aragonite gives a significant offset between reconstructed $\delta^{18} \mathrm{O}_{\mathrm{sw}}$-the aragonite is c. $1.5 \%$ lighter than the calculated calcite average $\delta^{18} \mathrm{O}_{\text {sw }}$ (Fig. 2D and Supplementary data). The Kele et al. ${ }^{27}$ equation, derived for fast-growing travertines, is believed to reflect (near) equilibrium conditions, yet differs from Daëron et al. ${ }^{28}$ in having a slightly steeper slope (Eq. 2). Kele et al. ${ }^{27}$ could not explain the different slope of the travertine curve by any physical or chemical parameter (including growth kinetics). For belemnite calcite, the close fit to the Kele et al. ${ }^{27}$ equation may imply that some biotically-driven fractionation of ${ }^{18} \mathrm{O}$ occurred during precipitation of the calcite from the belemnite body fluid (since the aragonite was precipitated from body fluid in equilibrium with seawater ${ }^{28}$ ).

At Christian Malford (Phaeinum subzone), it happens that the $\delta^{18} \mathrm{O}_{\text {sw }}$ average that is calculated for both aragonite and calcite is approximately $-1 \%$, the average expected ocean value for an ice-free world ${ }^{13}$. When using clumped temperatures and measured $\delta^{18} \mathrm{O}$ carbonate at other sites (Fig. 3 and references therein), we see greater deviations from this global average value, indicating that using a global average value is not representative of all localities, particularly at high and low latitudes and in semi-enclosed basins. Indeed, if another stable isotope equation is used for the belemnite calcites, we still see the large spread in reconstructed $\delta^{18} \mathrm{O}_{\text {sw }}$ (as great as $7 \% 0^{35,38,40}$, Fig. 3). It is clear from the present variation in oxygen isotope composition of surface waters, and from GCM models of $\delta^{18} \mathrm{O}_{s w}$, that applying a global average is unlikely to be representative of a particular location or water depth ${ }^{14,15}$. Alberti et al. ${ }^{62}$ proposed using an empirically derived equation for modern oceans, $-1 \%$ o to account for the absence of Polar ice, to estimate latitudinal $\delta^{18} \mathrm{O}_{\mathrm{sw}}$ trends. However, as highlighted by Alberti 


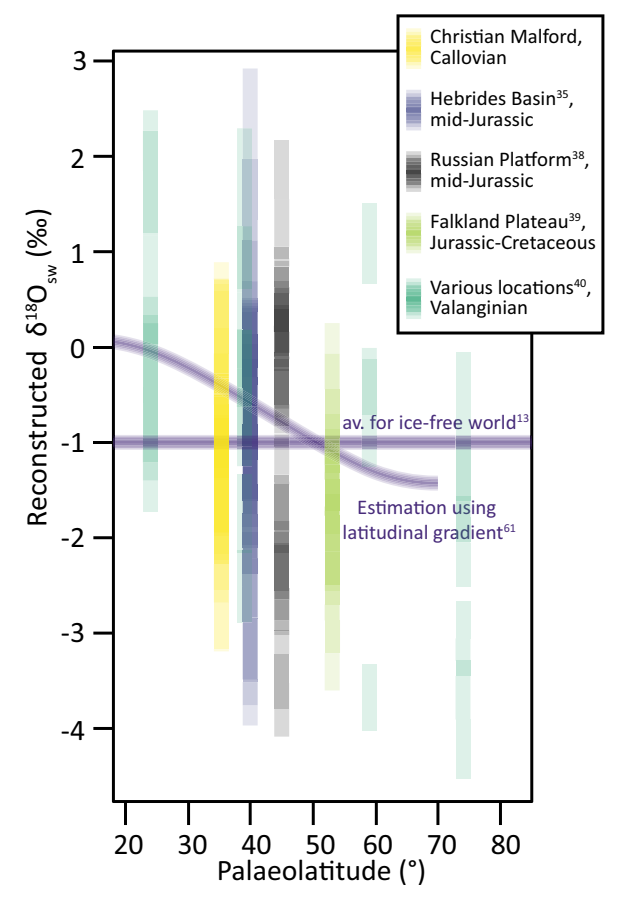

Figure 3. Reconstructed $\delta^{18} \mathrm{O}_{s w}$ based on clumped isotope temperatures using the Kele et al. ${ }^{27}$ equation according to palaeolatitude, compared to the average $\delta^{18} \mathrm{O}_{\mathrm{sw}}$ for an ice-free world ${ }^{13}$, and the equation proposed by Alberti et al. ${ }^{62}$. This equation may only be applied up to $70^{\circ 62}$. Data from belemnites and ammonites from this study (bivalves excluded as they may represent bottom water conditions), and belemnites from published Jurassic clumped isotope studies. Mid-Jurassic Russian Platform data (upper Callovian to lower Kimmeridgian; Cylindroteuthis and Pachyteuthis belemnites analysed) from Wierzbowski et al. ${ }^{38}$. Upper Jurassic-Lower

Cretaceous Falkland Plateau data (S. hemisphere; Belemnopsis belemnites analysed) are from Vickers et al. ${ }^{39}$. For both studies, $\Delta_{47}$ data were calculated using the [Brand] isotopic parameters ${ }^{64}$ and the temperatures calculated using the Wacker et al. ${ }^{65}$ calibration. Mid-Jurassic Hebrides Basin data (upper Callovian to lower Kimmeridgian; Cylindroteuthis and Pachyteuthis belemnites analysed) from Vickers et al. ${ }^{35}$ were recalculated to the new I-CDES carbonate-based reference frame ${ }^{53,54}$. Valanginian data (from both northern and southern hemisphere locations; 5 different belemnite genera analysed) from Price et al. ${ }^{40}$. It is not possible to recalculate the older datasets to the new I-CDES reference frame as not enough ETH standards were measured, yet the measured ETH-1 and ETH-3 standards are very close to the I-CDES ETH values, so the data are considered comparable. The different time periods are presented together as the global average will remain $-1 \%$, and the latitudinal $\delta^{18} \mathrm{O}_{\text {sw }}$ equation does not take into account palaeogeography. Error bars represent the maximum uncertainty in reconstructed $\delta^{18} \mathrm{O}_{\text {sw }}$ by the $95 \%$ confidence intervals on the clumped isotope temperatures and the SD of repeat analysis for $\delta^{18} \mathrm{O}_{\text {bel }}$.

et al. ${ }^{62}$, this does not take into account paleogeography, therefore it is unlikely to capture local $\delta^{18} \mathrm{O}_{\text {sw }}$ variations, particularly for the semi-enclosed basins that characterised the Mesozoic of Europe during the Jurassic (Fig. 1B). Using clumped isotopes temperatures to back-calculate $\delta^{18} \mathrm{O}_{s w}$ reveals that there are large variations in local $\delta^{18} \mathrm{O}_{\mathrm{sw}}$ that are not captured using either a global average or empirical gradients based on modern geography (Fig. 3). The studies of Wierzbowski et al. ${ }^{38}$ (Russian Platform) and Vickers et al. ${ }^{35}$ (Hebrides Basin) span broad age ranges and encompass changes in circulation patterns, as reflected in their very large ranges in $\delta^{18} \mathrm{O}_{\mathrm{sw}}$ values (Fig. 3). The study of Price et al..$^{40}$ demonstrates that for a single time-slice, latitudinal $\delta^{18} \mathrm{O}_{s w}$ as reconstructed by clumped isotope thermometry does show higher values at the equator than the poles (i.e. more similar to that proposed by Alberti et al. ${ }^{62}$ ), yet there is a broad and varied spread in the mid-latitudes. In the study of Price et al. ${ }^{40}$ some of the spread may arise from analysing different belemnite genera and species, which may have inhabited different depth habitats. Yet, since large ranges are observed in studies that use only one or two belemnite genera or families ${ }^{35,38,39}$, we believe that a significant portion of the variation arises from local $\delta^{18} \mathrm{O}_{\text {sw }}$ fluctuations. Thus, we anticipate that the majority of published values are still likely to under- or over-estimate local $\delta^{18} \mathrm{O}_{s w}$, leading to an over- or under-estimation in seawater temperatures, even if using the Kele et al. ${ }^{27}$ equation to calculate sea temperatures.

To conclude, we provide the first seawater $\Delta_{47}$ temperatures for the Jurassic based on samples that most likely have not been modified by diagenetic processes nor by ${ }^{13} \mathrm{C}-{ }^{18} \mathrm{O}$ bond reordering. We show that the palaeothermometry equations that have traditionally been applied to belemnite calcite are inappropriate, and, therefore, that reconstructions based on them grossly underestimate palaeotemperatures for the Mesozoic. The present study implies that ca. $11-12{ }^{\circ} \mathrm{C}$ needs to be added to the temperature estimates for the Jurassic and Cretaceous that were based on belemnites ${ }^{4-12}$ taking the average $\delta^{18} \mathrm{O}_{\text {calcite }}$ of combined belemnite datasets and the 2 standard 
deviation range $\mathrm{e}^{12}$. This has substantial implications for our understanding of the Mesozoic world and Greenhouse Earth-system states. It raises some of the lowest temperature estimates for the Jurassic period (such as the Bajocian "cold mode"; $\sim 7^{\circ} \mathrm{C}$ ) to values which approach modern mid-latitude sea surface temperatures, thereby undermining previously speculated "icehouse" phases ${ }^{9}$. The warm belemnite temperatures do not contradict cooler temperature estimates from co-occurring benthic organisms; rather, they may be used to understand vertical temperature profiles in the oceans.

\section{Methods}

The carbonate material used in this study all comes from a $2 \mathrm{~m}$ thick interval in the Callovian-aged Peterborough Member of the Oxford Clay Formation (Athleta Zone, Phaeinum subzone). The Peterborough Member consists of alternating organic-poor, shell-rich massive clay and organic-rich, variably shelly, fissile clay ${ }^{42,66}$ All material was collected from an excavation site at Christian Malford, Wiltshire, U.K. (Fig. 1). Published ICP-MS, SEM and CL work on selected Cylindroteuthis belemnite aragonite and calcite material indicates the exceptional quality of preservation of these carbonates ${ }^{42}$, as does the PXRD, ICP-OES, SEM, EBSD and EDS element maps presented in this study (Supplementary material Figs. S2, S3, S4, S5, S6, S7, S8, S9, S10, S11, S12). Estimates suggest a maximum burial depth of only c. 500 metres $^{45}$, indicating that significant post-depositional heating did not occur. Due to the limited amount of some of the aragonitic material (particularly phragmocones) it was not possible to analyse all samples for ICP-OES, SEM and PXRD, yet it is assumed that the analysed samples are representative for all samples used in this study because minimal variability was observed.

PXRD. Powder X-ray diffraction (PXRD) was carried out using a Stoe StadiP transmission (capillary) diffractometer with a copper anode at $30 \mathrm{~mA}, 40 \mathrm{kV}$ and a germanium 111 monochromator to produce Ka1 X-rays. The diffracted beam was collected by an $18^{\circ} 2 \theta$ Dectris Mythen $1 \mathrm{~K}$ silicon strip detector. Samples were loaded in $0.3 \mathrm{~mm}$ borosilicate glass capillaries, mounted and aligned on the goniometer head and set to spin continuously during data collection. Both data sets were scanned from 10 to $55^{\circ} 2 \theta$ stepping at $0.5^{\circ}$ and $5 \mathrm{~s} / \mathrm{step}$. The resultant raw data has a step of $0.015^{\circ} 2 \theta$. Machine alignment was monitored using an NBS silicon standard. Phase analysis was done using Bruker's "Eva" program ${ }^{67}$ interfaced with the Powder Diffraction File provided by the International Centre for Diffraction Data.

Microscopy. Scanning electron microscopy was undertaken on selected samples, in order to assess whether the original biomineral crystal habits are preserved, and to identify the best-preserved regions within the belemnite rostra. Analyses were performed using secondary electrons on an FEI Quanta Inspect 250 Scanning Electron Microscope under a high vacuum of 2.40 to $2.93 \cdot 10^{-4} \mathrm{~Pa}$ and an electron beam of $95-97 \mu \mathrm{A}$ at the Geological Museum in Copenhagen, out on selected aragonites from phragmocones, ammonites and bivalves analysed in this study.

For SEM-EDS and EBSD analysis, cross- and longitudinal- sections of a selected rostra were mounted in epoxy and mechanically polished down to a $0.25 \mu \mathrm{m}$ diamond solution grain size, followed by chemical-mechanical polishing using an alkaline solution of colloidal silica in a neoprene substrate. EBSD orientation mapping was performed on the coated sample $(\sim 2.5 \mathrm{~nm}$ carbon) in a Thermo Fischer-FEI Quanta 200F equipped with an EDAX Hikari EBSD camera and TEAM software for data acquisition at the Scientific Center for Optical and Electron Microscopy (ScopeM) at ETH Zurich. Acquisition was performed with an accelerating voltage of $20 \mathrm{kV}$, beam current of $8 \mathrm{nA}$, working distance of $17 \mathrm{~mm}$, and mapping step size of $1 \mu \mathrm{m}$. Post-acquisition cleaning included grain confidence index (CI) standardization followed by one step of grain CI correlation. All points with $\mathrm{CI}<0.1$ and grains with less than 10 pixels were removed to prevent artifacts in the calculations.

The SEM-EDS element maps were undertaken at the SEM laboratory at the Geological Survey of Denmark and Greenland (GEUS), which hosts a ZEISS sigma 300VP field emission scanning electron microscope that is equipped with 2 Bruker Xflash 6|30129 eV EDS detectors and a Bruker e-Flash FS EBSD detector. Element maps were acquired from infilled apical area to the outermost pyritised rim of the rostrum, covering the changes of growth ring density and mineralogical changes. The sets of transect section were obtained for the cross- and the longitudinal-section. Elements mapped ( $\mathrm{Ca}, \mathrm{Mg}, \mathrm{Fe}, \mathrm{Mn}, \mathrm{O})$ cover the range of possible carbonates, with aragonite distinguished by trace $\mathrm{Sr}$; the potential occurrence of apatite $(\mathrm{P})$, pyrite (Fe, $\mathrm{S}$ ), clays ( $\mathrm{Al}, \mathrm{Si}, \mathrm{Ba}, \mathrm{K}$ ) and quartz $(\mathrm{Si})$ was also tested.

ICP-OES. Minor element analyses were performed using an Agilent 5110 VDV ICP-OES at the Camborne School of Mines, University of Exeter, following methods laid out in detail in Ullmann et al. ${ }^{68}$. The minor element data are expressed as ratios to Ca. Fossil samples were dissolved in $2 \% \mathrm{v} / \mathrm{v} \mathrm{HNO}_{3}$ with a dilution factor of $\sim 16,000$, yielding a nominal Ca concentration of $25 \mu \mathrm{g} / \mathrm{g}$ in solution. Signal quantification was carried out using a four point calibration using a blank solution and three matrix matched calibration solutions made up from certified single element standards mixed to match the chemical composition of the analysed samples. Accuracy and precision of the analyses was controlled by multiple measurements of interspersed international reference materials (JLs-1 and AK) and a quality control solution (BCQ2). Repeatability of the measurements is generally better than $1 \%$ ( 2 relative standard deviations) unless affected by limited count rates (el/Ca $<\mathrm{c} .100$ times the quantification limit). Repeatability of element/Ca ratios in the latter case are $1 \mu \mathrm{mol} / \mathrm{mol}$ for $\mathrm{Mn} / \mathrm{Ca}$, $3 \mu \mathrm{mol} / \mathrm{mol}$ for $\mathrm{Fe} / \mathrm{Ca}, 0.3 \mathrm{mmol} / \mathrm{mol}$ for $\mathrm{S} / \mathrm{Ca}$ and $0.2 \mathrm{mmol} / \mathrm{mol}$ for P/Ca. Quantification limits for the measurements computed as six times the standard deviation of the measurement blank are $9 \mu \mathrm{mol} / \mathrm{mol}$ for $\mathrm{Mg} / \mathrm{Ca}$, $0.2 \mu \mathrm{mol} / \mathrm{mol}$ for Sr$/ \mathrm{Ca}, 1 \mu \mathrm{mol} / \mathrm{mol}$ for $\mathrm{Mn} / \mathrm{Ca}, 4 \mu \mathrm{mol} / \mathrm{mol}$ for $\mathrm{Fe} / \mathrm{Ca}, 0.4 \mathrm{mmol} / \mathrm{mol}$ for S $/ \mathrm{Ca}$ and $0.2 \mathrm{mmol} /$ $\mathrm{mol}$ for $\mathrm{P} / \mathrm{Ca}$. Due to the generally limited quantity of phragmocone material available, it was not possible to 
analyse all phragmocone samples for ICP-OES. ICP-OES data are reported and plotted in the Supplementary Material.

Clumped isotope thermometry. Powdered homogenized rostrum samples were collected from across the middle chambers (apex and outer edge avoided), away from the tip of the rostrum, using a Dremel drill. For the aragonitic material (phragmocones and ammonites), small pieces were picked off using tweezers, and powdered using an agate mortar and pestle. With the phragmocones, it was not possible to select specific chambers or homogenize across many chambers, due to limited aragonitic belemnite material remaining.

Clumped isotope measurements were carried out at the ETH Zurich using a ThermoFisher Scientific MAT253 mass spectrometer coupled to a Kiel IV carbonate preparation device, following the methods described in Müller et al. ${ }^{69}$. The Kiel IV device included a PoraPakQ trap kept at $-40{ }^{\circ} \mathrm{C}$ to eliminate potential organic contaminants. Samples were measured between May 2019 and December 2020 by measuring maximum 3 replicates of each sample per run which consists generally of 24 samples of $130-150 \mu \mathrm{g}$ interspersed with 20 replicates of each of the three carbonate standards ETH-1, ETH-2 and ETH- $3^{70}$. The samples were analysed in LIDI mode with $400 \mathrm{~s}$ of integration of sample and reference gas. The calculations and corrections were done with the software Easotope $\mathrm{e}^{71}$ using the revised "Brand parameters" for ${ }^{17} \mathrm{O}$ correction as suggested by Daëron et al. ${ }^{64}$. The data are reported with respect to the Intercarb carbon dioxide equilibration scale (I-CDES ${ }^{53}$. Temperatures were calculated using the Anderson et al. ${ }^{54}$ calibration which is based on the re-measurement of a series of samples that were used for previous calibrations. Their consistency with calibrations based on biogenic carbonates ${ }^{72-74}$ suggest that it is appropriate for marine biogenic carbonates. Corrections for aragonite were the same as for calcite except that we used the phosphoric acid oxygen isotope correction for aragonite of $1.00909^{75}$.

Received: 9 July 2021; Accepted: 9 September 2021

Published online: 27 September 2021

\section{References}

1. Tierney, J. E. et al. Past climates inform our future. Science 370, 6517 (2020).

2. Price, G. D. The evidence and implications of polar ice during the Mesozoic. Earth Sci. Rev. 48, 183-210 (1999).

3. Jenkyns, H. C., Jones, C. E., Gröcke, D. R., Hesselbo, S. P. \& Parkinson, D. N. Chemostratigraphy of the Jurassic System: Applications, limitations and implications for palaeoceanography. J. Geol. Soc. 159, 351-378 (2002).

4. Voigt, S., Wilmsen, M., Mortimore, R. N. \& Voigt, T. Cenomanian palaeotemperatures derived from the oxygen isotopic composition of brachiopods and belemnites: Evaluation of Cretaceous palaeotemperature proxies. Int. J. Earth Sci. 92, 285-299 (2003).

5. Dutton, A., Huber, B. T., Lohmann, K. C. \& Zinsmeister, W. J. High-resolution stable isotope profiles of a dimitobelid belemnite: Implications for paleodepth habitat and late Maastrichtian climate seasonality. Palaios 22, 642-650 (2007).

6. Wierzbowski, H. \& Joachimski, M. Reconstruction of late Bajocian-Bathonian marine palaeoenvironments using carbon and oxygen isotope ratios of calcareous fossils from the Polish Jura Chain (central Poland). Palaeogeogr. Palaeoclimatol. Palaeoecol. 254, 523-540 (2007)

7. Mutterlose, J., Malkoc, M., Schouten, S., Sinninghe Damsté, J. S. \& Forster, A. TEX86 and stable $\delta 180$ paleothermometry of early Cretaceous sediments Implications for belemnite ecology and paleotemperature proxy application. Earth Planet. Sci. Lett. 298, 286-298 (2010).

8. Dera, G. et al. Climatic ups and downs in a disturbed Jurassic world. Geology 39, 215-218 (2011).

9. Korte, C. \& Hesselbo, S. P. Shallow marine carbon and oxygen isotope and elemental records indicate icehouse-greenhouse cycles during the Early Jurassic. Paleoceanography 26 (2011).

10. Alberti, M., Fürsich, F. T., Pandey, D. K. \& Ramkumar, M. Stable isotope analyses of belemnites from the Kachchh Basin, western India: Paleoclimatic implications for the Middle to Late Jurassic transition. Facies 58, 261-278 (2012).

11. Veizer, J. \& Prokoph, A. Temperatures and oxygen isotopic composition of Phanerozoic oceans. Earth Sci. Rev. 146, 92-104 (2015).

12. Korte, C. et al. Jurassic climate mode governed by ocean gateway. Nat. Commun. 6, 10015 (2015).

13. Shackleton, N. \& Kennett, J. Paleotemperature history of the Cenozoic and the initiation of Antarctic glaciation: oxygen and carbon isotope analyses in DSDP Sites 277, 279, and 281. Vol. 29 (US Government Printing Office, 1975).

14. LeGrande, A. N. \& Schmidt, G. A. Global gridded data set of the oxygen isotopic composition in seawater. Geophys. Res. Lett. 33 (2006).

15. Zhou, J., Poulsen, C., Pollard, D. \& White, T. Simulation of modern and middle Cretaceous marine $\delta^{18} \mathrm{O}$ with an ocean-atmosphere general circulation model. Paleoceanography 23, PA3223 (2008).

16. Epstein, S., Buchsbaum, R., Lowenstam, H. A. \& Urey, H. C. Revised carbonate-water isotopic temperature scale. Geol. Soc. Am. Bull. 64, 1315-1326 (1953).

17. Craig, H. The measurement of oxygen isotope paleotemperatures. Stable Isotopes Oceanogr. Stud. Paleotemp. 23 (1965).

18. Anderson, T. F. \& Arthur, M. A. Stable isotopes in sedimentary geology and their application to sedimentologic and paleoenvironmental problems. In: society of Economic Paleontologists and Mineralogists Short Course Notes, Arthur, M.A. et al. (Eds), SEPM 10, 1-151 (1983).

19. Brand, U. et al. Oxygen isotopes and $\mathrm{MgCO}_{3}$ in brachiopod calcite and a new paleotemperature equation. Chem. Geol. 359, 23-31 (2013).

20. Takayanagi, H. et al. Intraspecific variations in carbon-isotope and oxygen-isotope compositions of a brachiopod Basiliola lucida collected off Okinawa-jima, southwestern Japan. Geochim. Cosmochim. Acta 115, 115-136 (2013).

21. Shackleton, N. J. Attainment of isotopic equilibrium between ocean water and the benthonic foraminifera genus Uvigerina: isotopic changes in the ocean during the last glacial. In: Labeyrie, L. (Ed.), Colloque international sur les méthodes quantitatives d'étude des variation du climat au sours du Pleistocene, CNRS Res., Colloquium, 219, 203-209 (1974).

22. Mulitza, S. et al. Temperature: $\delta^{18} \mathrm{O}$ relationships of planktonic foraminifera collected from surface waters. Palaeogeogr. Palaeoclimatol. Palaeoecol. 202, 143-152 (2003).

23. Killingley, J. \& Newman, W. ${ }^{18} \mathrm{O}$ fractionation in barnacle calcite: A barnacle paleotemperature equation. J. Mar. Res. 40, 893-902 (1982).

24. Hays, P. D. \& Grossman, E. L. Oxygen isotopes in meteoric calcite cements as indicators of continental paleoclimate. Geology 19, 441-444 (1991).

25. Leng, M. J. \& Marshall, J. D. Palaeoclimate interpretation of stable isotope data from lake sediment archives. Quatern. Sci. Rev. 23, 811-831 (2004). 
26. Coplen, T. B. Calibration of the calcite-water oxygen-isotope geothermometer at Devils Hole, Nevada, a natural laboratory. Geochim. Cosmochim. Acta 71, 3948-3957 (2007).

27. Kele, S. et al. Temperature dependence of oxygen-and clumped isotope fractionation in carbonates: a study of travertines and tufas in the 6-95 C temperature range. Geochim. Cosmochim. Acta 168, 172-192 (2015).

28. Daëron, M. et al. Most Earth-surface calcites precipitate out of isotopic equilibrium. Nat. Commun. 10, 429 (2019).

29. O’Neil, J. R., Clayton, R. N. \& Mayeda, T. K. Oxygen isotope fractionation in divalent metal carbonates. J. Chem. Phys. 51, 5547-5558 (1969).

30. Kim, S.-T. \& O'Neil, J. R. Equilibrium and nonequilibrium oxygen isotope effects in synthetic carbonates. Geochim. Cosmochim. Acta 61, 3461-3475 (1997).

31. Alberti, M., Fürsich, F. T. \& Pandey, D. K. The Oxfordian stable isotope record $\left(\delta^{18} \mathrm{O}, \delta^{13} \mathrm{C}\right)$ of belemnites, brachiopods, and oysters from the Kachchh Basin (western India) and its potential for palaeoecologic, palaeoclimatic, and palaeogeographic reconstructions. Palaeogeogr. Palaeoclimatol. Palaeoecol. 344, 49-68 (2012).

32. Zakharov, V. A. et al. Palaeoenvironments and palaeoceanography changes across the Jurassic/Cretaceous boundary in the Arctic realm: case study of the Nordvik section (north Siberia, Russia). Polar Res. 33, 19714 (2014).

33. Hoffmann, R. et al. Evidence for a composite organic-inorganic fabric of belemnite rostra: Implications for palaeoceanography and palaeoecology. Sed. Geol. 341, 203-215 (2016).

34. Stevens, K. et al. Belemnite biomineralization, development, and geochemistry: The complex rostrum of Neohibolites minimus. Palaeogeogr. Palaeoclimatol. Palaeoecol. 468, 388-402 (2017).

35. Vickers, M. L. et al. Unravelling Middle to Late Jurassic palaeoceanographic and palaeoclimatic signals in the Hebrides Basin using belemnite clumped isotope thermometry. Earth Planet. Sci. Lett. 546, 116401 (2020).

36. Jenkyns, H., Schouten-Huibers, L., Schouten, S. \& Sinninghe Damsté, J. Warm Middle Jurassic-Early Cretaceous high-latitude sea-surface temperatures from the Southern Ocean. Clim. Past 8 (2012).

37. Price, G. D. \& Passey, B. H. Dynamic polar climates in a greenhouse world: Evidence from clumped isotope thermometry of Early Cretaceous belemnites. Geology 41, 923-926 (2013).

38. Wierzbowski, H. et al. Clumped isotope record of salinity variations in the Subboreal Province at the Middle-Late Jurassic transition. Global Planet. Change 167, 172-189 (2018).

39. Vickers, M. L., Bajnai, D., Price, G. D., Linckens, J. \& Fiebig, J. Southern high-latitude warmth during the Jurassic-Cretaceous: New evidence from clumped isotope thermometry. Geology 47, 724-728 (2019).

40. Price, G. D., Bajnai, D. \& Fiebig, J. Carbonate clumped isotope evidence for latitudinal seawater temperature gradients and the oxygen isotope composition of Early Cretaceous seas. Palaeogeogr. Palaeoclimatol. Palaeoecol. 552, 109777 (2020).

41. Bajnai, D. et al. Dual clumped isotope thermometry resolves kinetic biases in carbonate formation temperatures. Nat. Commun. 11, 1-9 (2020).

42. Price, G. D., Hart, M. B., Wilby, P. R. \& Page, K. N. Isotopic analysis of Jurassic (Callovian) mollusks from the Christian Malford Lagerstätte (UK): Implications for ocean water temperature estimates based on belemnoids. Palaios 30, 645-654 (2015).

43. Glass, K. et al. Impact of diagenesis and maturation on the survival of eumelanin in the fossil record. Org. Geochem. 64, 29-37 (2013).

44. Wilby, P. R., Duff, K., Page, K. \& Martin, S. Preserving the unpreservable: a lost world rediscovered at Christian Malford,UK. Geol. Today 24, 95-98 (2008).

45. Hudson, J. \& Martill, D. The Peterborough Member (Callovian, Middle Jurassic) of the Oxford Clay Formation at Peterborough, UK. J. Geol. Soc. 151, 113-124 (1994).

46. Kenig, F., Hudson, J. D., Damsté, J. S. S. \& Popp, B. N. Intermittent euxinia: Reconciliation of a Jurassic black shale with its biofacies. Geology 32, 421-424 (2004).

47. Marland, G. The stability of $\mathrm{CaCO}_{3} \cdot 6 \mathrm{H}_{2} \mathrm{O}$ (ikaite). Geochim. Cosmochim. Acta 39, 83-91 (1975).

48. Chen, S. et al. Mechanism of Solid-state clumped isotope reordering in carbonate minerals from aragonite heating experiments. Geochim. Cosmochim. Acta 258, 156-173 (2019).

49. Henkes, G. A. et al. Temperature limits for preservation of primary calcite clumped isotope paleotemperatures. Geochim. Cosmochim. Acta 139, 362-382 (2014).

50. Stolper, D. A., Eiler, J. M. \& Higgins, J. A. Modeling the effects of diagenesis on carbonate clumped-isotope values in deep-and shallow-water settings. Geochim. Cosmochim. Acta 227, 264-291 (2018).

51. Fernandez, A. et al. Reconstructing the magnitude of Early Toarcian (Jurassic) warming using the reordered clumped isotope compositions of belemnites. Geochim. Cosmochim. Acta 293, 308-327. https://doi.org/10.1016/j.gca.2020.10.005 (2021).

52. Ritter, A. C. et al. Exploring the impact of diagenesis on (isotope) geochemical and microstructural alteration features in biogenic aragonite. Sedimentology 64, 1354-1380 (2017).

53. Bernasconi, S.M., Daëron, M., Bergmann, K., Bonifacie, M., Meckler, A.N., et al. InterCarb: A community effort to improve interlaboratory standardization of the carbonate clumped isotope thermometer using carbonate standards. hal-03094122 (2021). https:// doi.org/10.1002/essoar.10504430.4

54. Anderson, N. T. et al. A unified clumped isotope thermometer calibration $\left(0.5-1,100^{\circ} \mathrm{C}\right)$ using carbonate-based standardization. Geophys. Res. Lett. 48, e2020GL092069 (2021).

55. Hoffmann, R. \& Stevens, K. The palaeobiology of belemnites-foundation for the interpretation of rostrum geochemistry. Biol. Rev. 95, 94-123 (2020).

56. Grossman, E. L. \& Ku, T.-L. Oxygen and carbon isotope fractionation in biogenic aragonite: temperature effects. Chem. Geol. Isotope Geosci. Sect. 59, 59-74 (1986).

57. Fiebig, J., Daëron, M., Bernecker, M., Guo, W., Schneider, G., Boch, R., Bernasconi, S.M., Jautzy, J. \& Dietzel, M. Calibration of the dual clumped isotope thermometer for carbonates. Geochimica et Cosmochimica Acta, In press (2021).

58. Dennis, K. J., Cochran, J. K., Landman, N. H. \& Schrag, D. P. The climate of the Late Cretaceous: New insights from the application of the carbonate clumped isotope thermometer to Western Interior Seaway macrofossil. Earth Planet. Sci. Lett. 362, 51-65 (2013).

59. Davies, A. J., Davis, S. \& John, C. M. Evidence of taxonomic non-equilibrium effects in the clumped isotope composition of modern cephalopod carbonate. Chem. Geol. 578, 120317 (2021).

60. White, R., Dennis, P. \& Atkinson, T. Experimental calibration and field investigation of the oxygen isotopic fractionation between biogenic aragonite and water. Rapid Commun. Mass Spectrom. 13, 1242-1247 (1999).

61. Watkins, J. M. \& Hunt, J. D. A process-based model for non-equilibrium clumped isotope effects in carbonates. Earth Planet. Sci. Lett. 432, 152-165 (2015).

62. Alberti, M. et al. Stress in the tropics? Impact of a latitudinal seawater $\delta^{18} \mathrm{O}$ gradient on Middle Jurassic temperature reconstructions at low latitudes. Geology (2020).

63. Dera, G., Toumoulin, A. \& De Baets, K. Diversity and morphological evolution of Jurassic belemnites from South Germany. Palaeogeogr. Palaeoclimatol. Palaeoecol. 457, 80-97 (2016).

64. Daëron, M., Blamart, D., Peral, M. \& Affek, H. Absolute isotopic abundance ratios and the accuracy of $\Delta_{47}$ measurements. Chem. Geol. 442, 83-96 (2016).

65. Wacker, U. et al. Empirical calibration of the clumped isotope paleothermometer using calcites of various origins. Geochim. Cosmochim. Acta 141, 127-144 (2014). 
66. Hart, M. B., De Jonghe, A., Page, K. N., Price, G. D. \& Smart, C. W. Exceptional accumulations of statoliths in association with the Christian Malford lagerstätte (Callovian, Jurassic) in Wiltshire, United Kingdom. Palaios 31, 203-220 (2016).

67. Gates-Rector, S. \& Blanton, T. The powder diffraction file: A quality materials characterization database. Powder Diffr. 34, 352-360 (2019).

68. Ullmann, C. V. et al. Warm afterglow from the Toarcian Oceanic Anoxic Event drives the success of deep-adapted brachiopods. Sci. Rep. 10, 1-11 (2020).

69. Müller, I. A. et al. Carbonate clumped isotope analyses with the long-integration dual-inlet (LIDI) workflow: Scratching at the lower sample weight boundaries. Rapid Commun. Mass Spectrom. 31, 1057-1066 (2017).

70. Bernasconi, S. M. et al. Reducing uncertainties in carbonate clumped isotope analysis through consistent carbonate-based standardization. Geochem. Geophys. Geosyst. 19, 2895-2914 (2018).

71. John, C. M. \& Bowen, D. Community software for challenging isotope analysis: First applications of 'Easotope'to clumped isotopes. Rapid Commun. Mass Spectrom. 30, 2285-2300 (2016).

72. Breitenbach, S. F. et al. Coupled $\mathrm{Mg} / \mathrm{Ca}$ and clumped isotope analyses of foraminifera provide consistent water temperatures. Geochim. Cosmochim. Acta 236, 283-296 (2018).

73. Peral, M. et al. Updated calibration of the clumped isotope thermometer in planktonic and benthic foraminifera. Geochim. Cosmochim. Acta 239, 1-16 (2018).

74. Meinicke, N. et al. A robust calibration of the clumped isotopes to temperature relationship for foraminifers. Geochim. Cosmochim. Acta 270, 160-183 (2020).

75. Kim, S.-T., Mucci, A. \& Taylor, B. E. Phosphoric acid fractionation factors for calcite and aragonite between 25 and 75 C: Revisited. Chem. Geol. 246, 135-146 (2007).

\section{Acknowledgements}

Funding for this study was gratefully received from the Danish Council for Independent Research -Natural Sciences grant DFF-7014-00142 to C. Korte. We extend thanks to Martin Vickers, Department of Chemistry, UCL, London, for overseeing the Powder X-Ray Diffraction analysis on the carbonates. We would like to thank Madalina Jaggi at ETH Zurich for running the clumped isotope analyses on the carbonate samples. We thank our reviewers, Matthias Alberti and anonymous, and editorial board member Slah Boulila, for their constructive feedback reviewing the manuscript.

\section{Author contributions}

M.L.V. contributed the ideas, the main writing of the manuscript, preparation of all figures, and took part in sample preparation, analysis and interpretation for all methods. S.M.B. ran and interpreted the clumped isotope analysis at ETH Zurich, and wrote the methods and parts of the interpretation of the clumped isotope data in the manuscript. C.V.U. ran ICP-OES analysis at CSM, Penryn, and assisted in the interpretation of the data, and writing of the methods. S.L. undertook the preparation of the belemnite thick sections, and SE and EDS SEM mapping, with interpretation thereof. N.L. and L.G.M. undertook the EBSD analysis and interpretation of the EBSD data, and writing of the methods. G.D.P. and P.R.W. collected the samples and ran preliminary preservational quality checks on the material, and wrote the geological setting. I.W.H. undertook back-scattered electron SEM analysis of selected samples and interpretation thereof. S.P.H. provided interpretation of the data and contributed to the writing of the manuscript. C.K. provided the funding for the research, and contributed to the interpretation of the data. All authors reviewed the manuscript.

\section{Competing interests}

The authors declare no competing interests.

\section{Additional information}

Supplementary Information The online version contains supplementary material available at https://doi.org/ 10.1038/s41598-021-98528-1.

Correspondence and requests for materials should be addressed to M.L.V.

Reprints and permissions information is available at www.nature.com/reprints.

Publisher's note Springer Nature remains neutral with regard to jurisdictional claims in published maps and institutional affiliations.

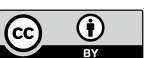

Open Access This article is licensed under a Creative Commons Attribution 4.0 International License, which permits use, sharing, adaptation, distribution and reproduction in any medium or format, as long as you give appropriate credit to the original author(s) and the source, provide a link to the Creative Commons licence, and indicate if changes were made. The images or other third party material in this article are included in the article's Creative Commons licence, unless indicated otherwise in a credit line to the material. If material is not included in the article's Creative Commons licence and your intended use is not permitted by statutory regulation or exceeds the permitted use, you will need to obtain permission directly from the copyright holder. To view a copy of this licence, visit http://creativecommons.org/licenses/by/4.0/.

(C) The Author(s) 2021 